\title{
Government Policy in Realizing Basic Education Metro
}

\author{
Apri Wahyudi, Zulela, Arita Marini, Choirudin, B. Ayshwarya, Phong Thanh Nguyen, K. \\ Shankar
}

\begin{abstract}
This paper presents government policy in realizing basic education metro. The policy of aid programs in the field of education with the aim of freeing the cost of education for students who are unable and lighten the burden for other students in order to support the achievement of the Basic Education Compulsory Education Program Through a policy program the central government provides funds to elementary and junior high schools to help reduce the burden of education costs that must be borne by parents. The cost of aid is given to schools to be managed by the provisions stipulated by the central government.
\end{abstract}

Index Terms: Government, policy, basic education, aid program

\section{INTRODUCTION}

Increasing needs in education, encouraged the Indonesian government to channel 6 aid funding for the continuity of education in Indonesia, the School Operational Aid Fund (BOS), the Family Hope Program (PKH), Non-Cash Food Aid (Rasta), Poor Student Aid (BSM), National Health Guarantee (JKN) [1]. However, the aid funding policy does not mean the cessation of educational problems, new problems arise related to the misuse of aid funds, and the ineffectiveness of managing aid funds, and the inaccurate targeting of aid [2]. Therefore, the cooperation of all elements is needed in realizing the effectiveness of management of aid funds in manifest basic education in Metro.

One phenomenon that appears even though the government has launched an aid program for a long time is the high dropout rates in basic education, noted population number of Metro-based education is not/has not schooled reached 39.087 people, primary school graduates recorded reach 24.048 people, thus total of population in Metro which has not graduated from elementary school has reached

Revised Manuscript Received on July 25, 2019.

Apri Wahyudi, Universitas Negeri Jakarta, Jakarta, Indonesia. E-mail: apriwahyudi_pd16s3@mahasiswa.unj.ac.id

Zulela, Universitas Negeri Jakarta, Jakarta, Indonesia. E-mail: zulela@unj.ac.id

Arita Marini, Universitas Negeri Jakarta, Jakarta, Indonesia. E-mail: arita250268@yahoo.co.id

Choirudin, Universitas Negeri Jakarta, Jakarta, Indonesia. choirudiniaimnumetro@gmail.com

B. Ayshwarya, Department of Computer Science, Kristu Jayanti College, Bangalore-560043, India.

Phong Thanh Nguyen, Department of Project Management, Ho Chi Minh City Open University (HCMCOU), Vietnam.

K. Shankar, School of Computing, Kalasalingam Academy of Research and Education, Krishnankoil, India.
57.562 from 165.579 or reached $35 \%$ in 2017 . This is certainly a special concern considering Metro as an education city [3]. Metro has a large number of very poor households (RTSM), which is 8.515 families and 16.061 people in the underprivileged group reached $9,89 \%$.

Public policy is a decision that is intended to overcome problems that arise in a particular activity carried out by government agencies in the framework of administering the government. In another perspective, Malone argues that public policy studies study government decisions in overcoming a problem that is of public concern[4].

According to Dunn, the process of policy analysis is a series of activities in the process of political activities. Political activity is interpreted as a policy-making process and visualized as a series of interdependent stages[5]. Education aid funding is our country's policy program for the world of education. As proof that the government is very concerned about the quality of education for the nation's children[6]. This is also part of the success of the basic education program. The government helps children's education finance elementary school.

So many governments have issued education aid fundis, but until now many poor people who have limited access to quality education, this is partly due to the high cost of education[7]. On the other hand, Law Number 20 of 2003 concerning the National Education System mandates that every citizen aged 7-15 years be obliged to attend basic education, known as the Compulsory Basic Education Learning Program[8]. The consequence of this is that the government is obliged to provide education services for all students at the basic education level (SD / MI and SMP / Mts and equivalent education units).

\section{RESPONSE TO GOVERNMENT POLICY}

Indonesian people respond to well government policy in providing aid and assistance. This matter is seen from a World Bank survey of School-Based Management[9]. It turned out that funding could reduce the dropout rate to $81 \%$; increasing the transition of elementary to junior high school students to $90 \%$; reduce school fees by up to $63 \%$; increase the entry of poor students to school up to $74 \%$; increasing the availability of educational facilities in schools to $94 \%$; increase school authority to $94 \%$; and increase student achievement by $90 \%$. Therefore the government's policy in providing funds increasingly optimistic me we can improve the quality

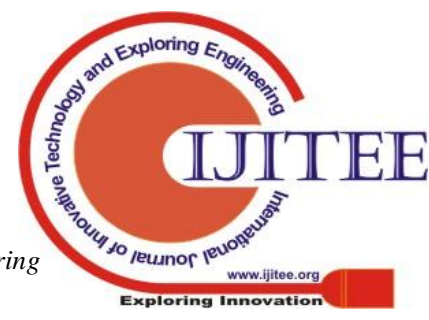


of primary education significantly[10].

Basic education in Metro reached a very significant number both seen in the number of schools, there are 107 elementary and junior high schools [11]. The Metro Government through the Education Authorities and the Social Service states the amount that has been spent for each aid each year as follows:

Table 1. Government Policy Aid for Education

\begin{tabular}{ccr}
\hline $\begin{array}{c}\text { Type of Aid } \\
\text { Funds }\end{array}$ & Level & \multicolumn{1}{c}{ Total } \\
\hline BOS & SD & Rp \\
& SMP & Rp 750.000/year \\
PKH & SD & Rp 1.890.000/year \\
& SMP & Rp 1.890.000/year \\
Rasta & SD & Rp 110.000/month \\
& SMP & Rp 110.000/month \\
Rp \\
BSM & SD & $450.000 /$ year \\
& SMP & Rp 750.000/year \\
JKN & SD & Rp 23.000/month \\
& SMP $23.000 /$ month \\
Rp \\
KIP & SD & Rp \\
& SMP & Rp 750.000/year \\
Average & & Rp 765.000/year \\
\hline
\end{tabular}

The amount of aid funds issued is an indicator of the seriousness of government policy in improving the quality of basic education in Metro. Certainly being a big hope based on the mandate of Law Number 20 of 2003 concerning the National Education System can be realized well.

\section{PROBLEMS AND SOLUTIONS GOVERNMENT POLICY IN ACHIEVING PRIMARY EDUCATION METRO}

Eliminating the subsidized education policy is not a solution, because it is at the core of education is the primary requirement to be fulfilled[12]. Constitution has mandated to provide free services for basic education. Therefore, the complete elimination of policy is not a solution to the crisis of managing funds[13].

However, at least there are several steps that the government might take to address these issues including:

1) Policy Review

The 1945 Constitution states that education is the right of all citizens, especially basic education for nine-year compulsory education is the main right for citizens of the State and State must seek financing. This is a great mandate and the main background why aid funds are present in the 9 -year compulsory education process. But in reality not all schools and not all citizens need and must be subsidized for this basic education, this is evident with some schools that do not receive funding, but still sell quality to their customers[14].

Reviewing does not mean the elimination of the program, but the renewal of the design of the assistance program can be a solution. It could be that the government rearranges funding for schools that are already financially advanced and also specific rules for citizens who are not eligible to receive subsidies[15].

2) Fair Funds

Fair does not mean equal, it can be different between one and the other, but technically and essentially the amount can be sufficient and can be used effectively and efficiently. Therefore, equitable funds have been put in place for the management of education subsidies[16]. It is not appropriate for students whose parents are financially capable, but enter and go to school in a school that receives subsidies from the government, so participation from the school is needed to record students who are worthy of subsidies.

If this equitable fund is truly implemented in the education subsidy fund management system, it is possible that in the future parents will assume that if they are classified as eligible citizens, they must send their children to subsidized schools, while those who do not belong to the category of eligible subsidies send their children to schools that are not subsidized. So that the concentration of funds will be directed towards improving the quality of education, and there is no quality gap between subsidized schools and non-subsidized schools. But of course, this fair fund is needed by a good Indonesian human nature, does not put the ego first in acting and is aware of public or social interests.

The effort to improve the accuracy of the target of poverty reduction programs through the integration of poverty data, Integrated Data Base (BDT) $40 \%$ of Metro residents included in the criteria of poor and vulnerable households, $15 \%$ of the lowest number was not all eligible for PKH at the same time get Rasta, BSM, JKN, and other aids. Coverage of Household Deciles 1 (poorest) with different programs (Literature, BSM, JKN). Records between programs in the poorest decile of $10 \%$ are still very low. This is because the coverage of the $\mathrm{PKH}$ program is still small and the Susesnas survey is difficult to capture small programs[17].
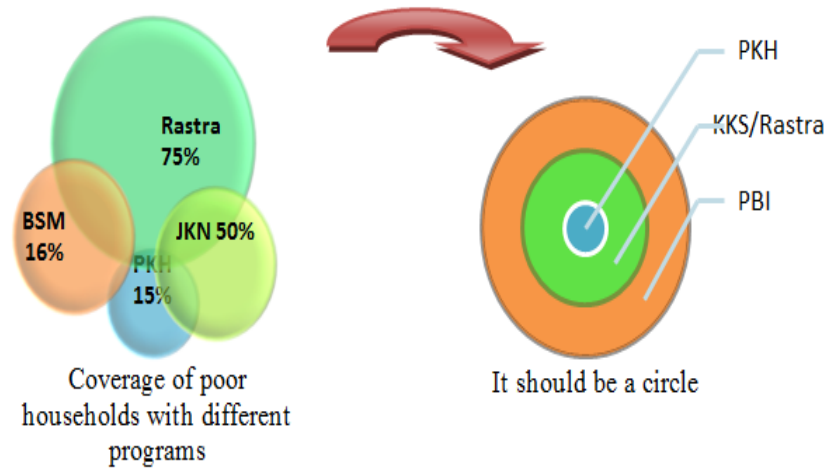

Figure 1. The Gap in Education Aid Programs

So that there is a need to equalize the number of variables for PBI, KKS, and PKH non-UDB data as well as integrated management and Social Welfare in Pustadin.

\section{3) Effective and Efficient Supervision}

Supervision is a function of management or administration. Supervision is an action that serves to pay attention to the conditions that occur in the field with the expected conditions of 
policymakers. The education subsidy policy contained in the aid program should have good supervision from the government because this is a government program or policy, so attention to the supervision process must also be considered.

So far the supervision that occurs in the management of aid funds is sufficient at the reporting level, while the implementation of the reality in the field is still lacking, the supervisors, offices or government, feel that they have enough reports on paper, even if it is seen in the field. with what is in the report, so that here is needed effective and efficient supervision to overcome abuse of authority in the use of funds. The inherent supervision and effectiveness of existing supervisory staff can be a solution for effective supervision.

The accuracy of the aid target to the community for program complementarity integrated with other aid programs such as energy subsidies, health, food assistance and so forth.

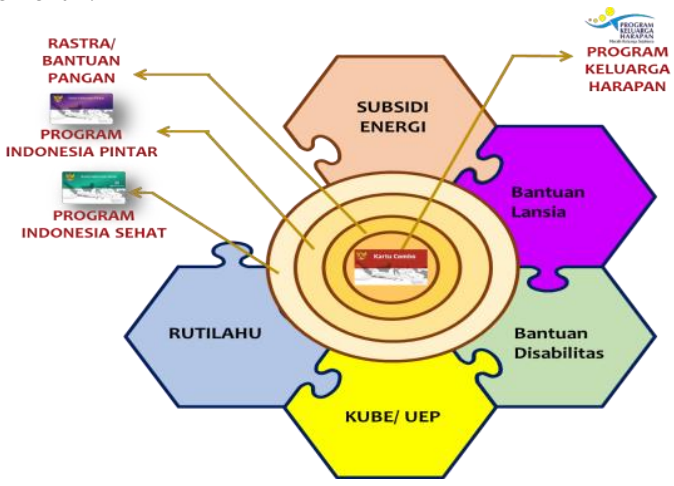

Figure 2. Accuracy of Goals for Program Complementarity

First, improving the quality of education services is (1) purchasing school supplies, and (2) extra school fees; the need for extracurricular fees. This is as stated in the Indonesia Smart Card (KIP) program, all needs for educational purposes so that they can be utilized properly. Second, the level of education level distribution. With the existence of educational assistance programs, the community can take advantage of this program well. This is closely related to the level of education level for all parties. Where the level of education for participants can fulfill educational needs, such as school supplies; uniforms, stationery and more. Besides, this conditional cash transfer can pay for school needs which are outside the payment principal (extra charge money). Through the Indonesia Smart Card (KIP), all participants can access education without having to be burdened for reasons of not having capital.

4) Assistance from Competent Experts

Not a few schools also make mistakes and abuse not intentionally, there are also factors of ignorance, or accidental so that the elements of education are deceived and misused. Therefore, assistance from competent experts can be a solution to this problem. The expert in question is not only a professor or lecturer from a financial expert but a minimum of people or social institutions who understand the management of education, so that understanding of the management of education will be a strong basis for the technical implementation of management of aid funds. This is because at school there are no professionals who handle school management, the only available staff is senior high school graduates or even junior high school, while managing this large amount of funds requires several main competencies, besides of course managerial competence.

\section{CONCLUSION}

The misuse of aid funds is found in many regions, the most frequent cases being inflating the number of students, misuse of funds, and even fictitious data and reporting often adorn newspapers about misappropriation of aid funds. It can also be triggered by the system running, the weak supervision and public participation are lacking, causing the purpose of their aid subsidies are becoming useless.

For this reason, preventive action is needed from every institution and element of the nation to progress and effectively manage aid funds. Among them are reviewing the policies that have been set. Another solution that can be tried is assistance by competent experts can facilitate the management and effectiveness of the use of aid funds. Fulfillment of eight national education standards, trustworthy leadership, the community plays a role and is critical in terms of education, the government is consistent with legislation and recruitment in the world of competency-based education.

\section{REFERENCES}

[1] "Kementerian Pendidikan dan Kebudayaan » Republik Indonesia." [Online]. Available: https://www.kemdikbud.go.id/main/blog/2018/12/program-bantuan -sosial-untuk-rakyat. [Accessed: 14-Jul-2019].

[2] A. Riddell and M. Niño-Zarazúa, "The effectiveness of foreign aid to education,” Int. J. Educ. Dev., vol. 48, pp. 23-36, May 2016.

[3] PKH Kota Metro, "Laporan Data Penerima Jumlah Keluarga Penerima Manfaat (KPM) PKH Kota Metro tahun 2013 sampai dengan tahun 2017."

[4] C. L and E. F. Malone, "Public Policy: Perspectives and Choices," p. 439, 2014

[5] R. Hoppe, "Heuristics for Practitioners of Policy Design: Rules-of-thumb for structuring unstructured problems.," Public policy Adm., vol. 33, no. 4, pp. 384-408, Oct. 2018.

[6] I. Mligo, "Enhancing Young Children's Access to Early Childhood Education and Care in Tanzania," in Contemporary Perspective on Child Psychology and Education, InTech, 2018.

[7] Delvi, "Manajemen Pendidikan Anak di Kalangan Keluarga Miskin," Manajer Pendidik., vol. 9, no. 2, pp. 115-126, 2015.

[8] Undang-Undang Republik Indonesia Nomor 20 Tahun 2003 Tentang Sistem Pendidikan Nasional.

[9] E. Winarti, "School-Based Management: the Challenges of Its Implementation," Orientasi Baru, vol. 20, no. 1, pp. 85-106, 2011

[10] Sukat, "Implementasi Manajemen Berbasis Sekolah/Madrasah (MBS/M) Dalam Upaya Peningkatan Mutu Pendidikan di MIN Hadiluwih Kabupaten Sragen Tahun Ajaran 2013/2014,” Program Pasca Sarjana Institut Agama Islam Negeri Surakarta, 2016.

[11] K. P. dan Kebudayaan, "Jumlah Data Satuan Pendidikan Provinsi Lampung," 2019. [Online]. Available: http://referensi.data.kemdikbud.go.id/index11.php?kode=120000\&1 evel $=1$.

[12] L. Arendse, "International Law Perspective," Broken Landsc., vol. 14, no. 6, pp. 259-294, 2015

[13] T. Handayani, "Menyongsong Kebijakan Pendidikan Menengah Universal: Pembelajaran Dari Implementasi Wajar Dikdas 9 Tahun," J. Kependud. Indones., vol. 7, no. 1, pp. 39-56, 2012 M. Maryanto, N. Khoiriyah, and S. Purwo Saputro, "The Law Politics in Indonesia's Pancasila and Citizenship 


\section{Government Policy in Realizing Basic Education Metro}

Education Curriculum Revitalization of 2013," Asian Soc. Sci., vol. 13, no. 9, p. 167, 2017.

[15] A. Saputra, "Allocation of Education Budget in Indonesia," Budapest Int. Res. Critics Inst. Humanit. Soc. Sci., vol. 1, no. 2, pp. 141-147, 2018.

[16] R. Education Association of South Africa and R. Ndhlovu, South African Journal of Education., vol. 34, no. 3. Educational Association of South Africa, 2014.

[17] D. J. S. D. J. P. dan J. S. K. S. RI, Buku Kerja Pendamping Dan Operator PKH. Jakarta: Direktorat Jenderal Perlindungan dan Jaminan Sosial Kementerian Sosial RI, 2015. 